\title{
ResearchArticle
}

\section{Correlation studies for seed yield and yield attributes in soybean [Glycine max (L.) Merrill]}

\author{
P.S. Chavan, H.V. Kalpande, S.V. Kalyankar and S.B. Borgaonkar
}

\begin{abstract}
SUMMARY
An investigation entitled as "Correlation for yield and yield contributing traits in soybean [Glycine max (L).Merrill.] was conducted during Kharif 2018 at Instructional Farm, Department of Agriculture Botany, Vasantrao Naik Marathwada Agriculture University, Parbhani. The experiment was laid out in Randomized Block Design with three replications and seven treatments viz., $\mathrm{T}_{1}$-untreated seeds, $\mathrm{T}_{2}$-Polymer coating, $\mathrm{T}_{3}-\mathrm{T}_{2}+$ Vitavax, $\mathrm{T}_{4}-\mathrm{T}_{3}+\mathrm{GA}_{3} 100 \mathrm{ppm}, \mathrm{T}_{5}-\mathrm{T}_{3}+\mathrm{CCC} 100 \mathrm{ppm}$, $\mathrm{T}_{6}-\mathrm{T}_{3}+$ NAA 50ppm, $\mathrm{T}_{7}-\mathrm{T}_{3}+\mathrm{IAA} 50 \mathrm{ppm}$. Seed yield is a complex character and is dependent on number of component characters. Therefore, study of relationship of characters with each other and with seed yield become more important in crop improvement programme. Therefore, it is essential to find out relative contribution of each of the component character with yield. In present study yield and yield contributing character of seed yield was positive and significant correlated with field plant height, number of branches per plant, chlorophyll content, leaf area, germination per cent, moisture per cent, total dry weight, 100 seed weight, oil content, protein content, harvest index and no. of seeds per pod. The results also obtained from this study days to 50 per cent flowering and days to harvest are negative significant to other yield and yield parameter.
\end{abstract}

Key Words : Seed quality, GA, Seed Germination, IAA, Protein content

How to cite this article : Chavan, P.S., Kalpande, H.V., Kalyankar, S.V. and Borgaonkar, S.B. (2020). Correlation studies for seed yield and yield attributes in soybean [Glycine max (L.) Merrill]. Internat. J. Plant Sci., 15 (2): 92-95, DOI: 10.15740/HAS/IJPS/15.2/92-95, Copyright@ 2020: Hind Agri-Horticultural Society.

Article chronicle : Received : 08.04.2020; Revised : 18.05.2020; Accepted : 04.06.2020

\section{MEMBERS OF THE RESEARCH FORUM}

Author to be contacted :

S. B. Borgaonkar, Upland Paddy Research Scheme, Vasantrao Naik Marathwada Krishi Vidyapeeth, Parbhani (M.S.) India

Email : borgaonkars@rediffmail.com

Address of the Co-authors:

P. S. Chavan, Agricultural School, Aurangabad (M.S.) India

H. V. Kalpande and S.V. Kalyankar, Department of Agriculture Botany, Vasantrao Naik Marathwada Krishi Vidyapeeth, Parbhani (M.S.) India 